Influence of Rootstock and Variety on Leaf Nutrient Concentration of Pear Grown on a Nutrient-Sufficient Soil

\author{
İrfan NAZLI 1 iD, İbrahim ERDAL ${ }^{2} \mathscr{8}$ (iD \\ ${ }^{1}$ Egirdir Fruit Research Institute, Isparta, ${ }^{2}$ Isparta University of Applied Sciences, Faculty of Agricultural Sciences and Technologies, \\ Department of Soil Science and Plant Nutrition, Isparta \\ ${ }^{1}$ https://orcid.org/0000-0002-1262-6540, ${ }^{2}$ https://orcid.org/0000-0001-8177-948X \\ $\square$ : ibrahimerdal@isparta.edu.tr
}

\section{ABSTRACT}

Study was aimed to investigate the effect of rootstock, variety and their combination on mineral nutrition of pear. For this reason, Deveci, Santa Maria and Akca varieties grafted on Quince A, Quince C, BA 29 and OHF 333 rootstocks were used as plant materials. To compare nutritional status of plants, N, P, K, Ca, Mg, Fe, Cu, Mn Zn and $\mathrm{B}$ analysis were made on leaf samples. According to results, it was seen that individual effect of rootstock and variety and their combinations had significant effect on pear mineral nutrition generally. Although there was a significant variation depending on rootstock and variety differences, we could not reach a certain result which rootstock and variety or their combinations were prominent on general mineral nutrient concentration of pear. We assumed that this was due to preventing of the effectiveness of rootstock or variety because of sufficient nutrient levels in the soil.

\section{Research Article}

$\begin{array}{ll}\text { Article History } & \\ \text { Received } & : 13.05 .2019 \\ \text { Accepted } & : 27.06 .2019\end{array}$

Keywords

Mineral nutrition

Pear

Rootstock

Variety

\title{
Besin Elementi Bakımından Yeterli Bir Toprakta Yetiştirilen Armudun Mineral Beslenmesi Üzerine Anaç ve Çeşidin Etkisi
}
ÖZET
Araştırmada armudun mineral beslenmesi üzerine anaç, çeşit ve onların kombinasyonlarının etkisini incelemek amaçlanmıştır. Bu nedenle, bitki materyali olarak Quince A, Quince C, BA 29 ve OH x F333 anaçlarına aşılanmış Deveci, Santa Maria ve Akca çeşitleri kullanılmıştır. Bitkilerin beslenme durumlarının karşılaştırılması için yaprak örneklerinde $\mathrm{N}, \mathrm{P}, \mathrm{K}, \mathrm{Ca}, \mathrm{Mg}, \mathrm{Fe}, \mathrm{Cu}, \mathrm{Mn} \mathrm{Zn}$ ve B analizleri yapılmıştır. Sonuçlar, Anaç ve çeşitler ile onların kombinasyonlarının armudun mineral beslenmesi üzerinde anlamlı derecede etkili olduğunu göstermiştir. Bu anlamlı etkiye rağmen, hangi anacın, çeşidin veya kombinasyonun armudun genel beslenme durumu üzerinde daha etkili olduğuna yönelik kesin bir sonuca ulaşlamamıştır. Bu durumda, topraktaki yeterli miktarda bulunan besin elementleri nedeniyle anaç veya çeşidin etkinliğinin engellenmiş olabileceği düşünülmektedir.

Araştırma Makalesi
Makale Tarihçesi
Geliş Tarihi : 13.05 .2019
Kabul Tarihi : 27.06 .2019
Anahtar Kelimeler
Mineral beslenme,
Armut
Anaç
Çeşit

To Cite : Nazlı İ, Erdal İ 2019. Influence of Rootstock and Variety on Leaf Nutrient Concentration of Pear Grown on a NutrientSufficient Soil. KSU J. Agric Nat 22(Ek Sayı 1): 141-147. DOI: 10.18016/ksutarimdoga.vi.563740

\section{INTRODUCTION}

There are many factors effecting plant nutrition and nutritional status of a plant. These factors can be classified under three main groups such as soil, environment and plant factors. Soil texture, depth, $\mathrm{pH}$, salinity, cation exchange capacity, $\mathrm{CaCO}_{3}$, organic matter, available nutrient concentrations and balance are some of the soil factors. Also, precipitation and its characteristics, humidity, temperature, lighting period etc. play roles on soil fertility and plant nutrition. Besides above factors, plant factors are the main criterion on determining the degree of impact of these factors. For instance, plant type and variety, age of plant, growth stage, root structure and other genotypic properties plays different roles on nutrient uptake ability of a plant (Erdal et al., 2008; Marschner, 2012). Nutrient uptake capacity of a plant varies from plant to plant even they are different genotypes of a plant type (Clark and Gross, 1986). These variations can be seen even they are grown on the same soil and the same conditions (Marschner, 2012 Kucukyumuk and Erdal 2011; Kucukyumuk et al. 2015). In horticultural production, rootstock and variety are the main two 
important factors influencing the performance and survival of a cultivar against un-favorable conditions. So, choosing proper rootstocks and variety is important for a successful orchard establishment. In order to get better plant growth and quality yield, nutrient removal and transport capacity of plant cultivars and their rootstocks should be considered (Tsipouridis et al., 1990; Kucukyumuk and Erdal 2011). In different studies, it was well documented that there were close relations among rootstock, variety and plant nutrition. Studies conducted by Fazio et al., (2015), Nava et al., (2018) on apples; Dayal et al., (2017) on mangos; Dubey and Sharma (2016) on lemon; Vijaya and Rao (2015) on grape; Reig et al., (2018) on plum; Sau et al., (2018) on mandarin; Mayer et al., (2018) are some of the recent works.

Turkey is among the most pear producing countries, but export is not satisfactory (FAO, 2018). Although, there might be several reasons for this, the most reasonable reason is fruit quality due to non-suitable rootstock and variety chose. Suitable rootstock and variety can improve yield amount and yield quality with different ways. For example, resistance to environmental effects such as pest and disease, drought, salinity, frost, nutrient deficiency etc. can vary between rootstocks and scions (Westwood, 1995; Hartman et al., 1997; Fazio et al., 2015; Mestre et al., 2017).

In this study, it was aimed to investigate the effect of rootstock and variety and their combinations on mineral nutrition of pear plant under nutrientsufficient soil condition.

\section{MATERIAL and METHODS}

\section{Plant Materials}

The study was carried out on Deveci, Santa Maria and Akça varieties grafted on Quince A (QA), Quince C (QC), BA 29 and $\mathrm{OHF} 333$ rootstocks. Some characteristics of varieties and rootstocks are given below (Fig 1).

\section{Varieties}

Deveci: It is an Anatolia originated medium strength and semi-splayed, late season pear variety. It has large-very large fruit. The lower part is wide and flattened. Fruit peel is rough, ground color is yellow. The time between full flowering and harvesting is 150160 days. It is very sensitive to fever blight (Fig 1 a).

Santa Maria: Italia originated mid-season pear variety. Tree has medium strong, growth is perpendicular. Fruit is semi-large, the neck is long, and expands through down. The time between full flowering and harvesting is $115-125$ days (Fig $1 b$ ).

Akca: Anatolia originated early season pear variety. Tree is strong, growth is semi-perpendicular. Fruit is small with short neck and expands through down. The time between full flowering and harvesting is $75-85$ days (Fig 1c).

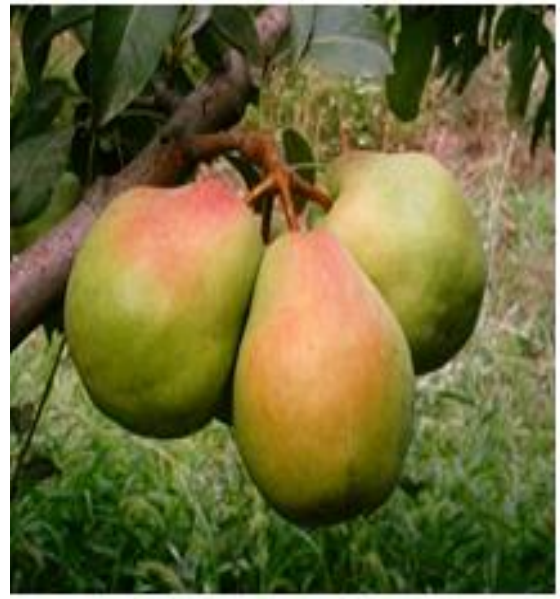

a

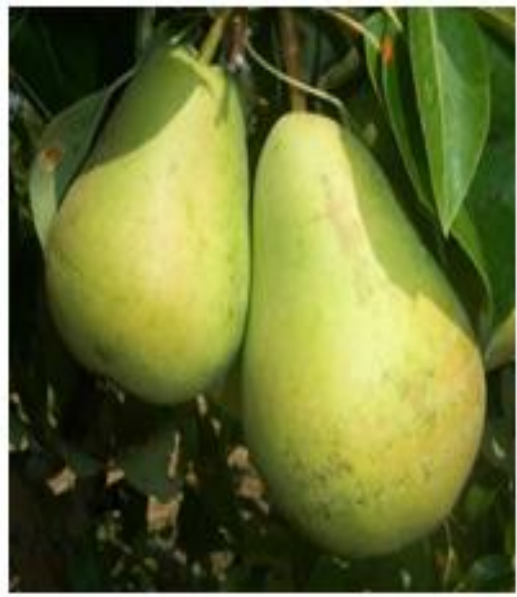

b

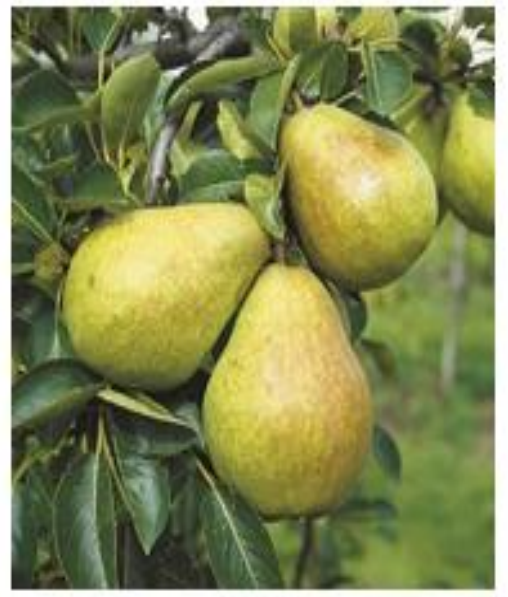

$\mathrm{C}$

Figure 1. The pear varieties used for the experiment

\section{Rootstocks}

Quince C (QC): It is a quince originated rootstock. It forms a weaker canopy than Quince A. It is sensitive to fire blight and soil lime content.

Quince A (QA): It has a medium vigor and forms a canopy of about $50 \%$ of the seedling. It has a shallow rooting system. It is sensitive to fire light and soil lime content.
BA 29: It forms a canopy of about $60 \%$ of seedling. Compatibility with pear varieties is better than Quince $\mathrm{A}$ and Quince $\mathrm{C}$ rootstocks. It is sensitive to chloroses, drought and cold, but tolerant to nematode.

OHF 333: It is a pear seedling rootstock. It has semistrong structure and deep rotting system. It is tolerant to fire blight, drought, chloroses and nematode. Approximate sizes of rootstocks have been seen below (Fig 2). 


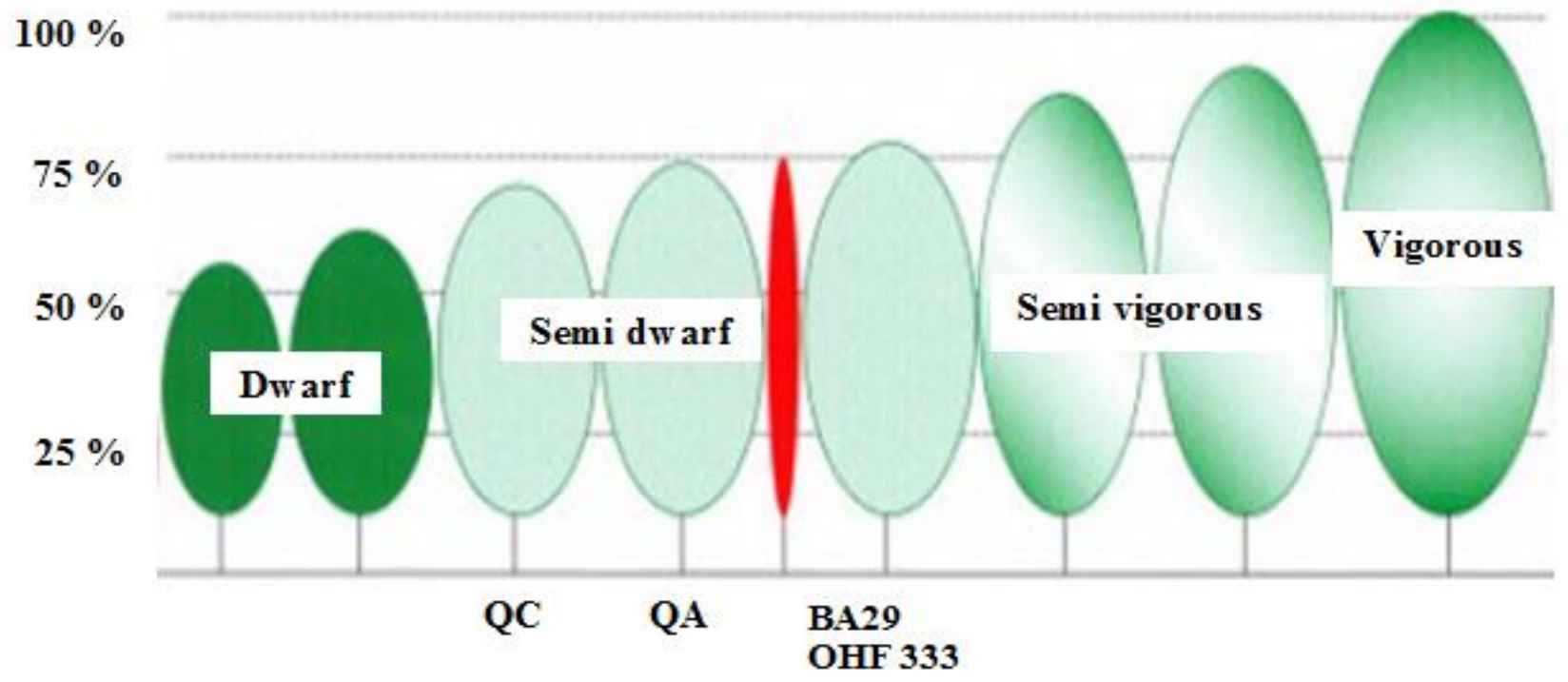

Figure 2. Approximate sizes of pear rootstocks used for the experiment (Modified from Campbell, 2003)

\section{Some Characteristics of the Soil}

Study was conducted at Egirdir Fruit Research Institute at Isparta-Turkey. The experimental soil was loam having $\mathrm{pH} 7.81$ (1:2.5 soil to water ratio), $6 \%$ $\mathrm{CaCO}_{3}$ (Allison and Moodie, 1965); $3.35 \%$ organic matter (Walckey and Black method, Jackson, 1967); $2040 \mathrm{mg} \mathrm{kg}^{-1}$ total N (Macro-Kjehldal method, Bremner 1965); $27 \mathrm{mg} \mathrm{kg}^{-1} 0.5 \mathrm{M} \mathrm{NaHCO}_{3}$ extractable $\mathrm{P}$ (Olsen et al., 1954); 303, 4950 and $898 \mathrm{mg} \mathrm{kg}^{-1}$ $\mathrm{NH}_{4} \mathrm{OAC}$ exchangeable $\mathrm{K}$, $\mathrm{Ca}$ and $\mathrm{Mg}$ (Knudsen et al., 1982). DTPA extractable (Lindsay and Norwell, 1978) $\mathrm{Fe}, \mathrm{Cu}, \mathrm{Mn}$ and $\mathrm{Zn}$ on Atomic absorption spectrophotometer were 17.8, 9.8, 6.3 and $1.1 \mathrm{mg} \mathrm{kg}^{-1}$, respectively. Boron concentration measured with ICP after the boiling of the soil in $0.01 \mathrm{M} \mathrm{CaCl}_{2}$ for 5 minutes was $0.85 \mathrm{mg} \mathrm{kg}^{-1}$ (Kacar, 2009).

\section{Experiment Set up}

The experiment was carried out in a split-plot design having 4 replications on 13 years old pear trees and each replication had 4 trees. As fertilization, $30 \mathrm{~kg}$ ha ${ }^{1} \mathrm{~N}, 15 \mathrm{~kg} \mathrm{ha}^{-1} \mathrm{P}, 10 \mathrm{~kg} \mathrm{ha}^{-1} \mathrm{~K}$ were applied from ammonium nitrate, mono ammonium phosphate and potassium nitrate.

\section{Leaf Analysis}

Leaf samples were taken from the four sides of trees after 8-10 weeks after full blooming. Samples were washed with dilute acid, top water and pure water. Then, dried, grinded and digested for mineral analysis. Nitrogen was measured according to modified Kjeldahl method (Bremner 1965). Other nutrients ( $\mathrm{P}, \mathrm{K}, \mathrm{Ca}$, $\mathrm{Mg}, \mathrm{Fe}, \mathrm{Cu}, \mathrm{Mn}, \mathrm{Zn}$ and $\mathrm{B}$ ) were determined using ICPOES (Spectro Arcos FHM 22) as described by Jones et al., (1991)

\section{Statistical Evaluation}

Data were analyzed with MSTAT-C program and differences between the means were separated by Duncan's Multiple Range Test $(\mathrm{P} \leq 0.05)$.

\section{RESULTS}

Rootstock and Variety Effect on Macronutrient Concentration of Pear

Leaf N, P, K, Ca and Mg concentrations of pear plants have been seen in Table 1. As indicated there, rootstock and variety difference had a significant effect on leaf $\mathrm{N}$ concentrations. While OHF 333 and QA rootstocks showed variation in terms of leaf $\mathrm{N}$ concentrations others took part in the same statistical classification. Deveci and Santa Maria cultivars contained the same amount of $\mathrm{N}$ and these concentrations were found to be significantly higher than Akca cultivar. Leaf $\mathrm{P}$ concentrations showed significant variation depending on Rootstock $\mathrm{x}$ variety interaction. Although leaf $\mathrm{P}$ concentrations varied between $0.193 \%$ (QA x Akca) and $0.278 \%$ (QC x Akca) with interactions, only the differences between QC x Akca - QA x Akca and OHF 333 x Deveci were significant. Differences among the other variations were not significant. Leaf $K$ concentrations have been affected from interactions of rootstock and variety. When looked at the results, it can be seen that there were quite differences among the interactions. The lowest $\mathrm{K}$ levels were measured on the leaves of QA x Akca interaction (0.99\%), whereas the highest $(1.98 \%)$ were at S Maria on OHF 333. Individual effect of rootstock and variety significantly affected leaf $\mathrm{Ca}$ and $\mathrm{Mg}$ concentrations. Both rootstocks and varieties were collected under two statistical groups for $\mathrm{Ca}$ and $\mathrm{Mg}$. The lowest $\mathrm{Ca}$ containing rootstock and variety were QA and Santa Maria, respectively. On the other hand, although there were not significant differences between other 
rootstocks, except $\mathrm{QA}$, the highest Ca was measured from the leaves of BA29 rootstock. Also, Deveci and Akca having the same statistical classification had significantly higher Ca compared to Santa Maria cultivar. Only, OHF 333 rootstock with the lowest $\mathrm{Mg}$ level significantly varied from the other rootstocks. Similarly, S Maria with the lowest Mg concentration differed from the Deveci and Akca varieties.

Table 1. Rootstock and variety effect on leaf N, P, K, Ca and Mg concentrations of pear.

\begin{tabular}{|c|c|c|c|c|c|}
\hline \multirow{2}{*}{ Variety } & \multicolumn{4}{|c|}{ Rootstocks } & \multirow{2}{*}{ Means } \\
\hline & OHF 333 & BA29 & $\mathrm{QA}$ & $\mathrm{QC}$ & \\
\hline \multicolumn{6}{|c|}{ N (\%) } \\
\hline Deveci & 2.02 & 2.00 & 1.72 & 2.02 & $1.94 \mathrm{~A}^{*}$ \\
\hline Santa Maria & 1.97 & 2.01 & 1.93 & 1.87 & $1.95 \mathrm{~A}$ \\
\hline Akca & 1.98 & 1.64 & 1.45 & 1.71 & $1.70 \mathrm{~B}$ \\
\hline Means & $1.99 \mathrm{~A}^{*}$ & $1.88 \mathrm{AB}$ & $1.70 \mathrm{~B}$ & $1.87 \mathrm{AB}$ & 1.86 \\
\hline \multicolumn{6}{|c|}{$\mathrm{P}(\%)$} \\
\hline Deveci & $0.198 b^{* *}$ & $0.210 \mathrm{ab}$ & $0.250 \mathrm{ab}$ & $0.217 \mathrm{ab}$ & 0.22 \\
\hline Santa Maria & $0.210 \mathrm{ab}$ & $0.245 \mathrm{ab}$ & $0.217 \mathrm{ab}$ & $0.270 \mathrm{ab}$ & 0.24 \\
\hline Akca & $0.217 \mathrm{ab}$ & $0.250 \mathrm{ab}$ & $0.193 \mathrm{~b}$ & $0.278 \mathrm{a}$ & 0.23 \\
\hline Means & 0.21 & 0.23 & 0.22 & 0.26 & 0.23 \\
\hline \multicolumn{6}{|c|}{ K (\%) } \\
\hline Deveci & $1.38 \mathrm{cde}$ & $1.21 \mathrm{de}$ & $1.44 \mathrm{bcde}$ & $1.67 \mathrm{abcd}$ & 1.43 \\
\hline Santa Maria & $1.98 \mathrm{a}$ & $1.95 \mathrm{ab}$ & $1.92 \mathrm{ab}$ & $1.87 \mathrm{abc}$ & 1.93 \\
\hline Akca & 1.70abcd & $1.27 \mathrm{de}$ & $0.99 \mathrm{e}$ & $1.27 \mathrm{de}$ & 1.30 \\
\hline Means & 1.67 & 1.48 & 1.45 & 1.60 & 1.55 \\
\hline \multicolumn{6}{|c|}{$\mathrm{Ca}(\%)$} \\
\hline Deveci & 1.28 & 1.65 & 1.12 & 1.23 & $1.32 \mathrm{~A}$ \\
\hline Santa Maria & 1.01 & 1.04 & 0.977 & 1.06 & $1.02 \mathrm{~B}$ \\
\hline Akca & 1.20 & 1.22 & 1.08 & 1.27 & $1.19 \mathrm{~A}$ \\
\hline Means & $1.16 \mathrm{AB}$ & $1.31 \mathrm{~A}$ & $1.06 \mathrm{~B}$ & $1.19 \mathrm{AB}$ & 1.18 \\
\hline \multicolumn{6}{|c|}{$\mathrm{Mg}(\%)$} \\
\hline Deveci & 0.320 & 0.443 & 0.413 & 0.390 & $0.392 \mathrm{~A}$ \\
\hline Santa Maria & 0.200 & 0.270 & 0.263 & 0.277 & $0.252 \mathrm{~B}$ \\
\hline Akca & 0.317 & 0.410 & 0.430 & 0.443 & $0.400 \mathrm{~A}$ \\
\hline Means & $0.279 \mathrm{~B}$ & $0.374 \mathrm{~A}$ & $0.369 \mathrm{~A}$ & $0.370 \mathrm{~A}$ & 0.348 \\
\hline
\end{tabular}

*Capital letters shows the differences between the means of main factors (rootstocks and varieties)

**: Small letters shows the interaction effects.

Rootstock and Variety Effect on Micronutrient Concentration of Pear

Effects of rootstocks and varieties on leaf micronutrient concentration of pear have been given in Table 2. As indicated there, rootstock $\mathrm{x}$ variety interaction significantly affected leaf $\mathrm{Fe}$ concentrations. If an evaluation is made generally, Akca variety grafted on all rootstocks had higher Fe concentration when compared to other rootstock $\mathrm{x}$ variety combinations. Also, Deveci cultivar grafted on $\mathrm{QC}$, took the same statistical place with the Akca $\mathrm{x}$ rootstock combinations. The lowest Fe was determined on the leaf of QC x Deveci combination. Depending on rootstock $\mathrm{x}$ variety combinations, a quite significant variation was determined for leaf $\mathrm{Cu}$ concentrations. The lowest $\mathrm{Cu}$ was measured on the leaf of Akca cv. grafted on QA, whereas the highest was measured on the leaf of Deveci cultivar on QA rootstock. Also leaf $\mathrm{Mn}$ concentrations showed significant variation depending on the rootstock $\mathrm{x}$ variety combinations. The lowest Mn was measured on the leaves of Santa Maria for all rootstocks. Deveci on QA and Akca on QA and QC had the highest Mn concentrations. Pear leaves $\mathrm{Zn}$ concentrations varied between $30.3 \mathrm{mg} \mathrm{kg}{ }^{-1}$ (OHF 333 x Santa Maria) and $56.2 \mathrm{mg} \mathrm{kg}^{-1}$ (QC x Akça). Individual effects of main factors had significant effects on leaf B concentrations. Depending on the rootstocks, they were separated in two statistical groups. OHF 333 with the highest B concentration differed from other three rootstocks. In terms of variety, they were grouped in 3 classifications. While, Deveci cultivar had the lowest B concentration, Akca cultivar had the highest. Santa Maria cultivar took place between them.

\section{DISCUSSION}

Rootstocks and variety individually or their interactions significantly affected leaf nutrient concentrations. Although there were some rootstocks $\mathrm{x}$ variety combinations which are in the same statistical group in terms of leaf nutrient concentrations, some of the combinations had quite different nutrient concentrations. Looking at the individual effects of rootstocks and varieties on pear nutrient 
concentrations, we determined variable response to the different nutrients. For instance, QA had the lowest $\mathrm{N}, \mathrm{Ca}$ and $\mathrm{B}$ containing rootstock, but in terms of $\mathrm{Mg}$, it was one of the most efficient rootstocks. Also,
OHF 333 sustained the most efficient rootstock on $\mathrm{N}$, $\mathrm{Ca}$ and $\mathrm{B}$, whereas, it was the most in-efficient rootstock in $\mathrm{Mg}$ and some other nutrients.

Table 2. Rootstock and variety effect on leaf $\mathrm{Fe}, \mathrm{Cu}, \mathrm{Mn}, \mathrm{Zn}$ and $\mathrm{B}$ concentrations of pear.

\begin{tabular}{|c|c|c|c|c|c|}
\hline \multirow{2}{*}{ Variety } & \multicolumn{4}{|c|}{ Rootstock } & \multirow{2}{*}{ Means } \\
\hline & OHF 333 & BA29 & QA & $\mathrm{QC}$ & \\
\hline \multicolumn{6}{|c|}{$\mathrm{Fe}\left(\mathrm{mg} \mathrm{kg}^{-1}\right)$} \\
\hline Deveci & $75.2 \mathrm{ab} * *$ & $76.8 \mathrm{ab}$ & $79.5 \mathrm{a}$ & $56.7 \mathrm{c}$ & 72.1 \\
\hline Santa Maria & $58.4 \mathrm{c}$ & $55.6 \mathrm{c}$ & $62.5 \mathrm{bc}$ & $63.7 \mathrm{bc}$ & 60.1 \\
\hline Akca & $79.1 \mathrm{a}$ & $84.5 \mathrm{a}$ & $85.7 \mathrm{a}$ & $88.3 \mathrm{a}$ & 84.4 \\
\hline Means & 70.9 & 72.3 & 75.9 & 69.6 & 72.2 \\
\hline \multicolumn{6}{|c|}{$\mathrm{Cu}\left(\mathrm{mg} \mathrm{kg}^{-1}\right)$} \\
\hline Deveci & $14.0 \mathrm{c}$ & $16.1 \mathrm{abc}$ & $22.3 \mathrm{a}$ & $15.1 b c$ & 16.9 \\
\hline Santa Maria & $16.0 \mathrm{abc}$ & $21.7 \mathrm{a}$ & $21.2 \mathrm{ab}$ & $15.9 \mathrm{abc}$ & 18.7 \\
\hline Akca & $13.2 \mathrm{c}$ & $9.73 \mathrm{~cd}$ & $6.40 \mathrm{~d}$ & $9.83 \mathrm{~cd}$ & 9.78 \\
\hline Means & 14.4 & 15.9 & 16.7 & 13.6 & 15.1 \\
\hline \multicolumn{6}{|c|}{$\mathrm{Mn}\left(\mathrm{mg} \mathrm{kg}^{-1}\right)$} \\
\hline Deveci & $125 \mathrm{c}$ & $181 \mathrm{ab}$ & $218 \mathrm{a}$ & $129 \mathrm{c}$ & 163 \\
\hline Santa Maria & $64 d$ & $45 \mathrm{~d}$ & $63 d$ & $125 \mathrm{c}$ & 74 \\
\hline Akca & $136 \mathrm{bc}$ & $168 \mathrm{abc}$ & $195 \mathrm{a}$ & $194 a$ & 173 \\
\hline Means & 108 & 131 & 158 & 149 & 137 \\
\hline \multicolumn{6}{|c|}{$\mathrm{Zn}\left(\mathrm{mg} \mathrm{kg}^{-1}\right)$} \\
\hline Deveci & $37.2 \mathrm{bc}$ & $55.6 \mathrm{a}$ & $55.5 \mathrm{a}$ & $46.3 \mathrm{ab}$ & 48.6 \\
\hline Santa Maria & $30.3 c$ & $33.6 \mathrm{bc}$ & $36.3 \mathrm{bc}$ & $44.5 \mathrm{ab}$ & 36.2 \\
\hline Akca & $45.9 \mathrm{ab}$ & $46.6 \mathrm{ab}$ & $50.8 \mathrm{a}$ & $56.2 \mathrm{a}$ & 49.9 \\
\hline Means & 37.8 & 45.3 & 47.5 & 49.0 & 44.9 \\
\hline \multicolumn{6}{|c|}{$\mathrm{B}\left(\mathrm{mg} \mathrm{kg}^{-1}\right)$} \\
\hline Deveci & 29.1 & 20.4 & 19.4 & 19.5 & $22.1 \mathrm{C}^{*}$ \\
\hline Santa Maria & 33.8 & 21.9 & 21.2 & 25.6 & $25.6 \mathrm{~B}$ \\
\hline Akca & 52.7 & 29.3 & 26.2 & 30.2 & $34.6 \mathrm{~A}$ \\
\hline Means & $38.5 \mathrm{~A}^{*}$ & $23.9 \mathrm{~B}$ & $22.3 \mathrm{~B}$ & $25.1 \mathrm{~B}$ & 27.4 \\
\hline
\end{tabular}

*Capital letters shows the differences between the means of main factors (rootstocks and varieties)

$* *$ : Small letters shows the interaction effects.

Similar variable findings were observed on the varieties as well. Differences in leaf nutrient concentration among the varieties and rootstocks are can be attributed to the inherent capacity of the varieties and rootstocks to take nutrients and their translocation in the plants (Meland, 2010; Fazio et al., 2015; Mestre et al., 2015). Previous studies indicated that plant can take different amount of nutrients even they are grown in the same conditions (Clark and Gross, 1986; Erdal et. al., 2008; Kucukyumuk and Erdal 2011; Erdem and Ozturk, 2012; Ikinci et al., 2014). Also, structure of root system, it's density, surface area, cation exchange capacities etc. influence plant's nutrient absorbing capacity (Marschner, 2012). Variations of root exudates and their properties depending on the rootstocks might play a role on nutrients availability to plants by means of rhizosphere acidification and chelating properties (Rengel 2001; Dakora and Phillips, 2002; Marschner, 2012). There might be other reasons for these variations. For example, resistance of a rootstock or variety against to abiotic or biotic stresses can be an advantage of a plant to receive more nutrients from the soils (Rengel 2001; Fazio et al., 2015). One of the other nutrient concentration variations can be the differences in plant size of varieties. As indicated before, nutrient demand and uptake generally increase with plant size and it's biomass (Mugasha et al., 2013; Peng et al., 2019). At the same time, physiological need of varieties had an important effect on nutrient requirement.

Although there were significant variations between rootstocks and variety and their combinations for some nutrient concentrations in the leaves, we could not see prominent rootstock or variety or their combination on pear nutrient concentration. This may be due to nutrient supplying capacity of the experiment orchard's soil. Nutrient concentrations were sufficient generally (Keren and Bingham 1985; Alpaslan et al. 2005) and about all nutrient concentrations in the leaves were between the sufficiency levels (Jones et al., 1991). This may have blocked the effectiveness of rootstock $\mathrm{x}$ variety combinations on specific nutrient uptake capacity. Similarities and proximities of the 
rootstocks in terms of plant size may be the other factor.

It can be concluded that it is better to work with nutrient deficient soils to reach certain results on which rootstock and variety or their combinations effective on plant's mineral nutrition. And the results should be revealed with the findings of other probable factors effecting plant's nutrient concentrations.

\section{ACKNOWLEDGEMENT}

This paper was produced from the master thesis of Irfan NAZLI. Study was financially supported by SDU, BAP with the number of 4909-YL1-17.

\section{REFERENCES}

Allison LE, Moodie CD 1965. Carbonate. In C.A. Black et al. (Eds.), Methods of Soil Analysis. (pp. 13791400), Madison, WI, USA: Am. Soc. of Agron. Inc. Part 2, Agronomy 9.

Alpaslan M, Guneş A, Inal A 2005. Deneme Tekniği. Ankara Üniversitesi Ziraat Fakültesi Yayınları, No: 1543.

Bremner JM 1965. Total Nitrogen 1. Methods of Soil Analysis. Part 2. Chemical and Microbiological Properties, 1149-1178.

Campbell J 2003. Pear Rootstock. NWS Agriculture, Edt. Noad B., ISSN: Orange Agricultural Institute. 0725-7759. The State of New South Wales.

Clark RB, Gross RD 1986. Plant Genotype Differences to Iron. Journal of Plant Nutrition, 9 (3-7): 471-491.

Dakora FD, Phillips DA 2002. Root Exudates as Mediators of Mineral Acquisition in Low-Nutrient Environments. In Food Security in NutrientStressed Environments: Exploiting Plants' Genetic Capabilities (pp. 201-213). Springer, Dordrecht.

Dayal V, Dubey AK, Singh SK, Sharma RM, Pandey RN 2017. Effect of Polyembryonic Rootstocks on Leaf Mineral Composition of Five Cultivars under Inceptisol. The Horticultural Society of India (Regd.), 74(2): 210-213.

Dubey AK, Sharma RM 2016. Effect of Rootstocks on Tree Growth, Yield, Quality and Leaf Mineral Composition of Lemon (Citrus limon (L.) Burm.). Scientia Horticulturae, 200: 131-136.

Erdal I, Askin MA, Kucukyumuk Z, Yildirim F, Yildirim A 2008. Rootstock has an Important Role on Iron Nutrition of Apple Trees. World Journal of Agricultural Sciences, 4 (2): 173-177.

Erdem H, Ozturk B 2012. Effect of Foliar Applied Zinc on Yield, Mineral Element Contents and Biochemical Properties of Pear Varieties Grafted to BA-29 Rootstock. Journal of the Faculty of Agriculture, 7(1): 93-106.

FAO 2018. Food and Agriculture Organization of the United Nations. http: // www. fao. org/ faostat

Fazio G, Chang L, Grusak MA, Robinson TL 2015. Apple Rootstocks Influence Mineral Nutrient
Concentration of Leaves and Fruit. NY Fruit Q, 23: 11-15.

Ikinci A, Bolat I, Ercisli S, Kodad O 2014. Influence of Rootstocks on Growth, Yield, Fruit Quality and Leaf Mineral Element Contents of Pear Cv. Santa Maria' in Semi-Arid Conditions. Biological Research, 47(71): 1-8.

Jackson ML 1967. Soil chemical analysis, New Delhi: Prentice Hall of India Private Limited.

Jones JB Jr, Wolf B, Mills HA 1991. Plant Analysis Handbook. A Practical Sampling, Preparation, Analysis, and Interpretation Guide, Micro-Macro Publishing, Inc: Athens, GA.

Kacar B 2009. Soil Analysis (Second Press). Nobel Press. 1387.

Keren R, Bingham FT 1985. Boron in Water, Soils, and Plants. Advanced Soil Science, 1: 229- 276.

Knudsen D, Peterson GA, Pratt PF 1982. Lithium, Sodium, and Potassium. Methods of Soil Analysis. Part 2. Chemical and Microbiological Properties, 225-246.

Kucukyumuk Z, Erdal I 2011. Rootstock and Cultivar Effect on Mineral Nutrition, Seasonal Nutrient Variation and Correlations among Leaf, Flower and Fruit Nutrient Concentrations in Apple Trees. Bulgarian Journal of Agricultural Science, 17(5): 633-641.

Kucukyumuk Z, Kucukyumuk C, Erdal I, Eraslan F 2015. Effects of Different Sweet Cherry Rootstocks and Drought Stress on Nutrient Concentrations. Journal of Agricultural Sciences, 21(3): 431-438.

Lindsay WL, Norvell WA 1969. Development of a DTPA Micronutrient Soil Test, Soil Science Society of American Proceeding, 35, 600-602.

Marschner P 2012. Mineral Nutrition of Higher Plants, 3rd Ed. Academic Press, San Diego, CA, USA.

Mayer NA, Ueno B, Nava G, Neves TRD 2018. Leaf Nutrient Content on Seven Plum Cultivars with Grafted by Budding or Own-Rooted Trees. Revista Brasileira de Fruticultura, 40 (3): 1-12.

Meland M 2010. Performance of Six European Plum Cultivars on Four Plum Rootstocks Growing in A Northern Climate. Acta Agriculturae Scandinavica Section B-Soil and Plant Science, 60(4): 381-387.

Mestre L, Reig G, Betrán J, Pinochet J, Moreno MA 2015. Influence of Peach-Almond Hybrids and Plum-Based Rootstocks on Mineral Nutrition and Yield Characteristics of 'Big Top'Nectarine in Replant and Heavy-Calcareous Soil Conditions. Scientia Horticulturae, 192: 475-481

Mugasha WA, Bollandsås OM, Eid T 2013. Relationships between Diameter and Height of Trees in Natural Tropical Forest in Tanzania. Southern Forests: A Journal of Forest Science, 75: 221-237.

Nava G, Ciotta MN, Pasa MDS, Boneti JIDS 2018. Mineral Composition of Leaves and Fruits of Apple 'Fuji'on Different Rootstocks in the Region of São 
Joaquim-SC. Revista Brasileira de Fruticultura, 40(2): 1-10.

Olsen SR 1954. Estimation of Available Phosphorus in Soils by Extraction with Sodium Bicarbonate. United States Department of Agriculture; Washington.

Peng H, Yan Z, Chen Y, Zhao X, Han W 2019. Effects of Body Size and Root to Shoot Ratio on Foliar Nutrient Resorption Efficiency in Amaranthus Mangostanus. American Journal of Botany, 106 (3): 363-370.

Reig G, Forcada CF, Mestre L, Jiménez S, Betrán JA, Moreno MÁ 2018. Horticultural, Leaf Mineral and Fruit Quality Traits of Two 'Greengage' Plum Cultivars Budded on Plum Based Rootstocks in Mediterranean Conditions. Scientia Horticulturae, 232: 84-91.

Rengel Z 2001. Genotypic Differences in Micronutrient Use Efficiency in Crops. Communications in Soil
Science and Plant Analysis, 32(7-8): 1163-1186.

Sau S, Ghosh SN, Sarkar S, Gantait S 2018. Effect of Rootstocks on Growth, Yield, Quality, and Leaf Mineral Composition of Nagpur Mandarin (Citrus reticulata Blanco.), Grown in Red Lateritic Soil of West Bengal, India. Scientia Horticulturae, 237: 142-147.

Tsipouridis C, Simonis AD, Bladenopoulou S, Isaakidis A, Stylianidis D 1990. Nutrient Element Variability in The Leaves of Peach Trees, in Relation to Cultivar and Rootstocks. In 23 rd international Horticulture Congress. Firenze, August.

Vijaya D, Rao BS 2015. Effect of Rootstocks on Petiole Mineral Nutrient Composition of Grapes (Vitis vinifera L. Cv. Thompson Seedless). Current Biotica, 8(4): 367-374.

Westwood MN 1995. Temperate-Zone Pomology: Physiology And Culture. 3rd Ed. Timber Press, Portland, Oregon. 